\title{
Notes on the fauna and taxonomy of longicorn-beetles (Coleoptera: Cerambycidae) of Near East and Transacaucasia. I
}

\author{
Заметки о фауне и таксономии жкуков-усачей \\ (Coleoptera: Cerambycidae) БАижнего Востока и Закавказья. I
}

\author{
D.G. Kasatkin \\ А.Г. Касаткин
}

Rostov branch of FSI “VNIIKR", 20 $0^{\text {th }}$ line, 43/16, Rostov-on-Don 344037 Russia. E-mail: dorcadion@yandex.ru Ростовский филиал ФГУ “ВНИИКР”, 20-я линия, 43/13, Ростов-на-Дону 344037, Россия.

KEY WORDS: Near East, Cerambycidae, new records, host plants, morphology, bionomie, new synonymy.

КЛЮЧЕВЫЕ СЛОВА: Ближний Восток, Cerambycidae, новые указания, кормовые растения, морфология, биономия, новая синонимия.

ABSTRACT. New data on the distribution of some Cerambycidae species from the Near East is presented as the result of processing the author's fieldworks and studying museums materials. In addition, a new information on the bionomics of some rare species is given. The taxonomic position of several species of the genus Phytoecia Dejean, 1835 is clarified. The following new synonymes are proposed: Phytoecia irakensis Breuning, $1967=$ Ph. prasina Reitter, 1911 syn.n., Purpuricenus mesopotamicus Ali, $1987=$ P. wachanrui Levrat, 1858 syn. n.

РЕЗЮМЕ. Новые данные о распространении некоторых видов Cerambycidae на Ближнем Востоке представлены как результат полевых исследований автора и изучения музейных материалов. Приведена новая информация о биономии и кормовых растениях некоторых редких видов жуков-усачей. Прояснена таксономическая позиция некоторых видов рода Phytoecia Dejean, 1835. Предложена следующая синонимия: Phytoecia irakensis Breuning, $1967=$ Ph. prasina Reitter, 1911 syn.n., Purpuricenus mesopotamicus Ali, $1987=$ P. wachanrui Levrat, 1858 syn. n.

The examined material is deposited in the following collections:

NMHD - Museum Natural History Denmark; HNHM - Natural History Museum of Hungary; NMW - Naturhistorisches Museum Wien; ZIN - Zoological Institute of Russian Academia of

Science; cDK - Denis Kasatkin collection; cAZ - Andrey Zubov collection.
Cortodera napolovi Danilevsky, 2015

Figs 1, 6 .

MATERIAL: 4 +, $50^{7}$, Turkey, Mush prov., Buglan pass, 22-25 05 2011, leg. Kasatkin D. (cDK); 59 , $70^{7}$, Mush prov., near Varto, Kharabelkup, 10-11 05 2009, leg. Kasatkin D. (cDK).

NOTES. This species was described from Eastern Turkey (Mush Prov., Buglan pass) and was characterized by the author as similar to $C$. colchica Reitter, 1890. It is mistake in our opinion, because the male genital structure allows us to conclude that $C$. napolovi belongs to the "alpina" speciesgroup. Cortodera colchica and allied species havn't the large sclerite in the medial part of the endophallus, while it is specific character of $C$. alpina Ménétries, 1832 (Figs 4-6). In addition, such well-known characters as the shape of lateral lobes (Figs 1-3) and penis (Figs 7-8), confirm belonging $C$. napolovi to the "alpina" species-group.

Anastrangalia montana (Mulsant et Rey, 1863)

MATERIAL: $40^{\top}, 2{ }^{\circ}$, Lebanon, Akkar, $2.5 \mathrm{~km}$ SE Qoubaiyat, $34^{\circ} 33^{\prime} 9.52^{\prime \prime} \mathrm{N} 36^{\circ} 17^{\prime} 45.76^{\prime \prime} \mathrm{E}, 22-2305$ 2018, leg. Kasatkin D (cDK).

NOTES. Distributed in Southern Turkey, Cyprus and Northern Syria [Löbl, Smetana, 2010; Ali, Rapuzzi, 2016; Danilevsky, 2020b]. The serie of this species was collected in a coniferous forest in North Lebanon (new record for the country).

Pedostrangalia (Neosphenalia) kurda Sama, 1997

MATERIAL: 4 ㅇ, $50^{\top}$, Iran, Kermanshakh prov., near Shamshir vill., 20-22 05 2015, on Apiaceae flowers, leg. Kasatkin D. (cDK).

NOTES. According to the Catalogue [Danilevsky, 2020b], this species is widespread in Near East and Transcaucasia: Turkey, Iraq, Armenia, Georgia and Iran. Data on the possible distribution of $P$. kurda in Georgia and Armenia are based on the publication of Miroshnikov [2011] and are unconfirmed. The record for Iran (as P. emmipoda Mulsant, 1863) is based on the work of Villiers [1967], who listed two locality: Karand (apparently Semnan Province) and Ghasr-eChirin (Kermanshakh Province). The record of P. kurda in

How to cite this article: Kasatkin D.G. 2021. Notes on the fauna and taxonomy of longicorn-beetles (Coleoptera: Cerambycidae) of Near East and Transacaucasia. I // Russian Entomol. J. Vol.30. No.3. P.297-304. doi: 10.15298/rusentj.30.3.07 
Semnan requires confirmation in our opinion, while the presence of this species in Kermanshah is confirmed by our material.

Purpuricenus mesopotamicus Ali, 1987

= Purpuricenus wachanrui Levrat, 1858 syn.n.

MATERIAL. 20 $0^{7}$, Iraq, Mossul prov., Siakh-Gyuivez, [Moc-
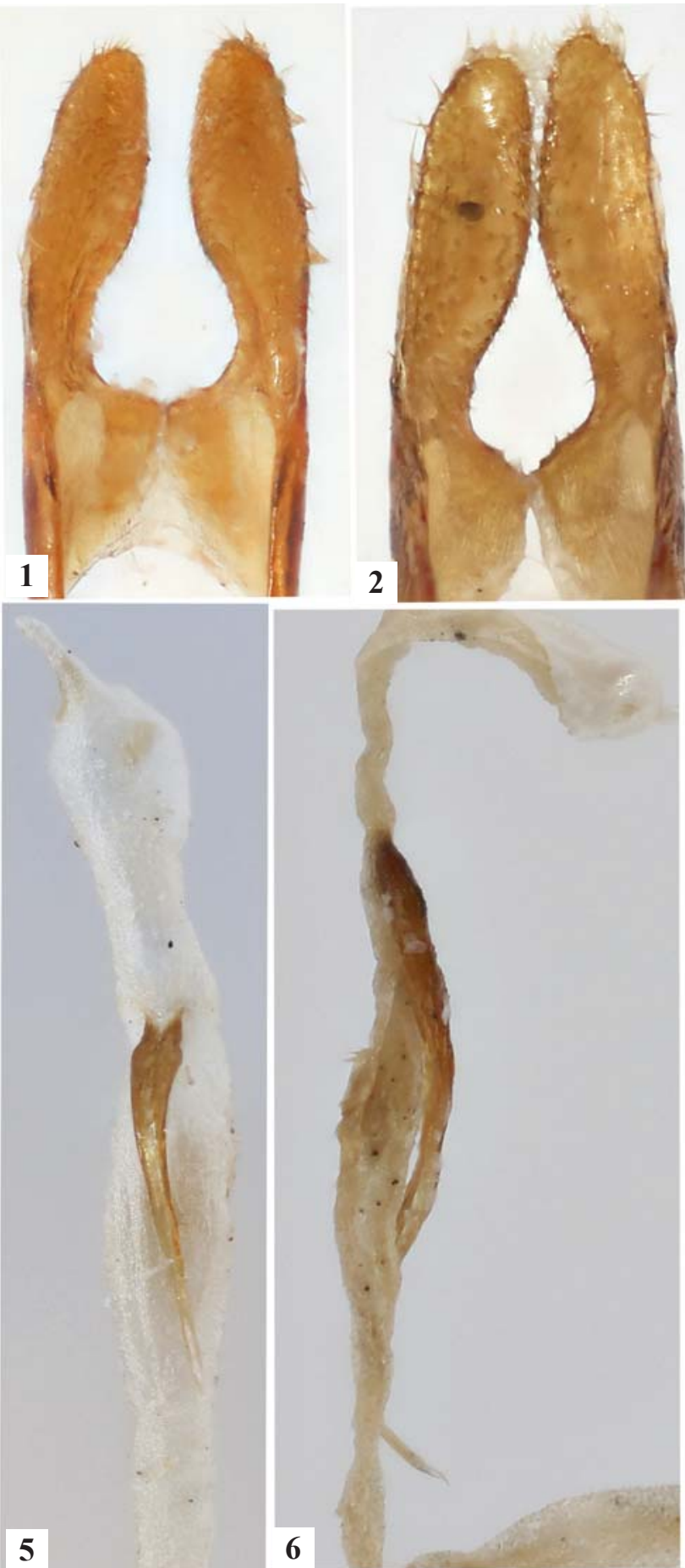

3

сульский вил., с. Сиях-Гювез], 21061914 (ZIN); 307, Turkey, Bulgan Gec., 18-20 06 2005, 1800 m, E. et P. Hajdaj leg. (cDK); $30^{7} 1$ 웅, Turkey, Tunceli prov., near Pülümür vill., 09062010 , leg. Kasatkin D. (cDK); $\sigma^{\prime}$, Turkey, Bitlis prov., Bashan, near Van Lake, 9-11 07 2007, Shokhin I. (cDK); Iran, 50 4ㅇ Kermanshakh prov., near Shamshir vill., 20-22 05 2015, on Apiaceae flowers, leg. Kasatkin D. (cDK); 20 1옹, Iran, near Kermanshakh, 15052017 , leg. Kasatkin D. (cDK).

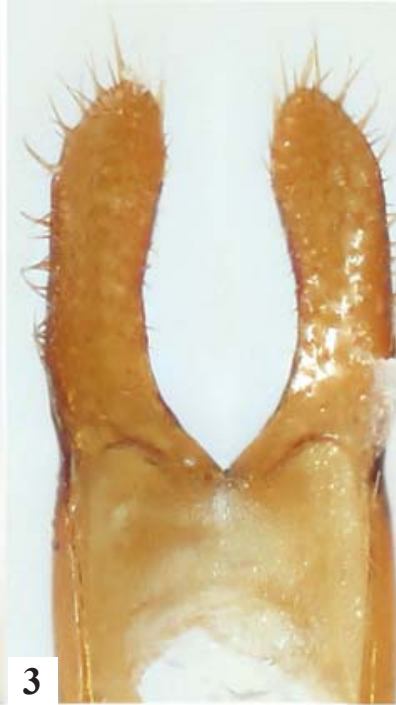

7

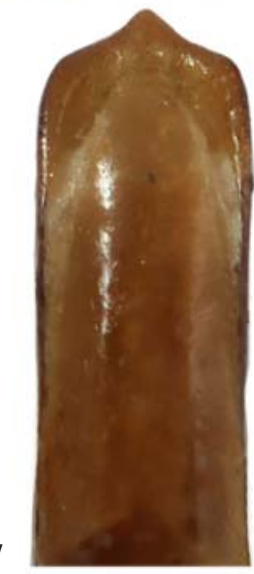

8

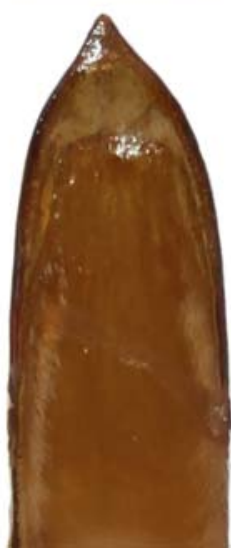

4

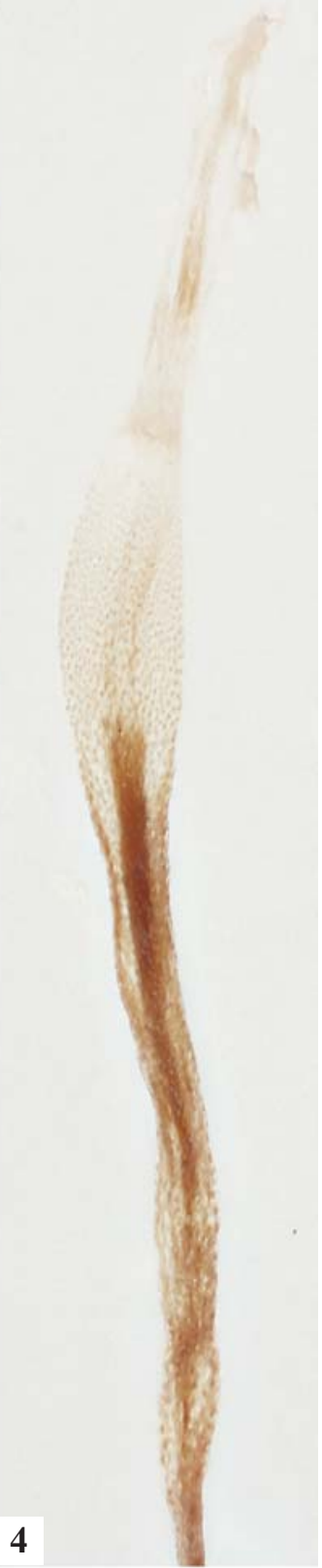

Figs 1-8. Detail of male genitalia some Cortodera Mulsant, 1863: 1, 6- Cortodera napolovi Danilevsky, 2015; 2, 5, 7 - C. alpina Ménétries, 1832; 3-4, 8-C. colchica Reitter, 1890; 1-3 - lateral lobes; 4-6 - medial part of endophallus; 7-8 - apex of penis.

Рис. 1-8. Детали морфоологии гениталий самцов некоторых Cortodera Mulsant, 1863: 1, 6 - Cortodera napolovi Danilevsky, 2015; 2, 5, 7 - C. alpina Ménétries, 1832; 3-4, 8-C. colchica Reitter, 1890; 1-3-боковые лопасти; 4-6-средняя доля эндофаллуса; 7-8 - вершина пениса. 

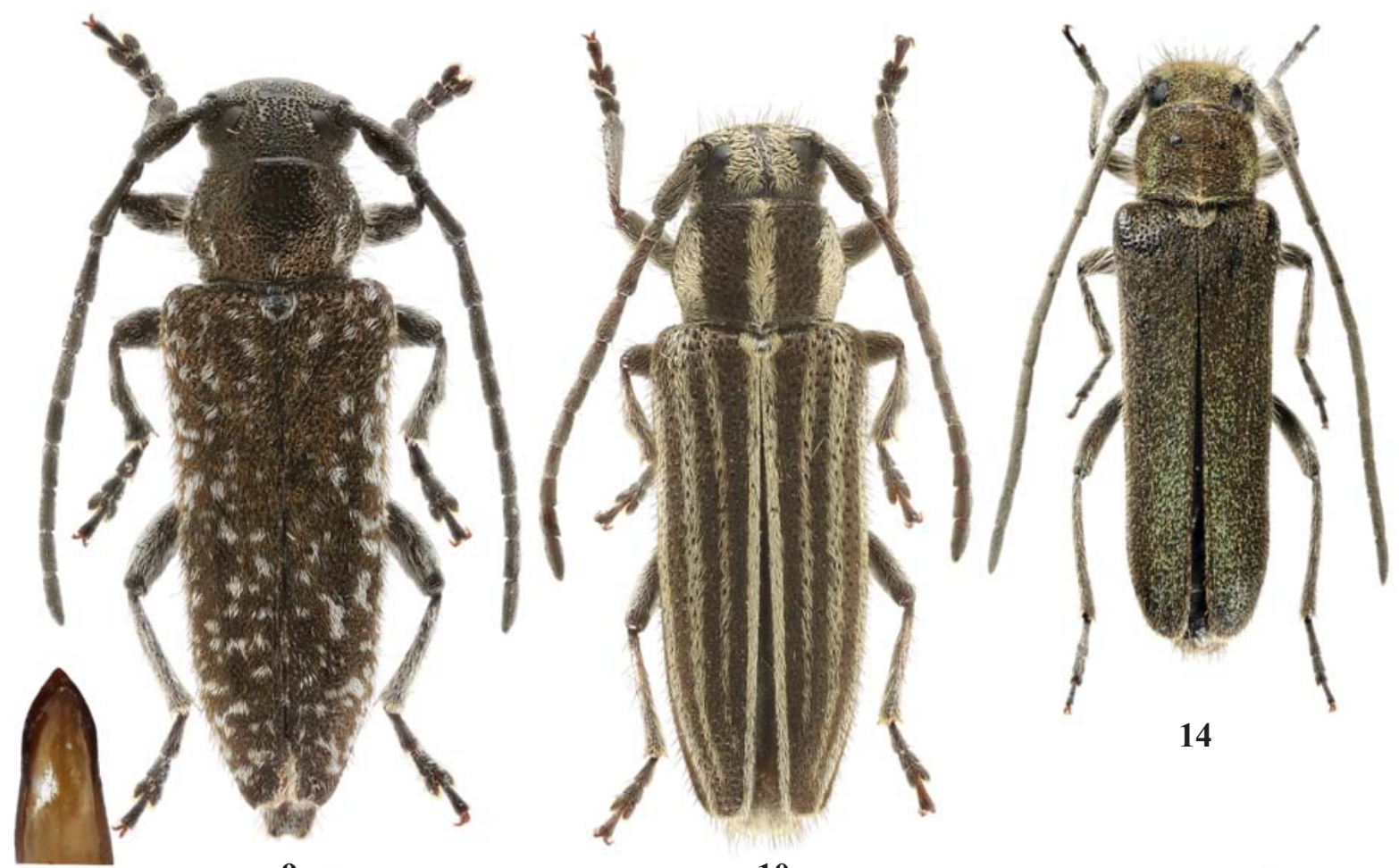

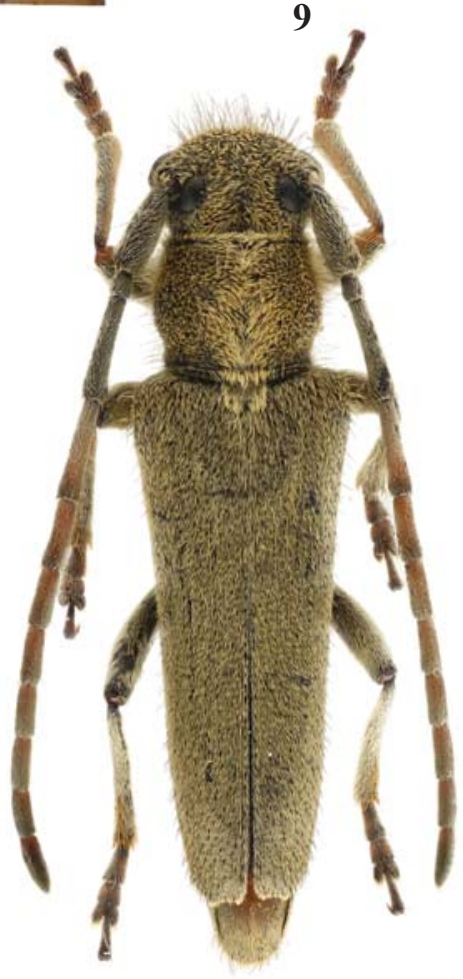

11

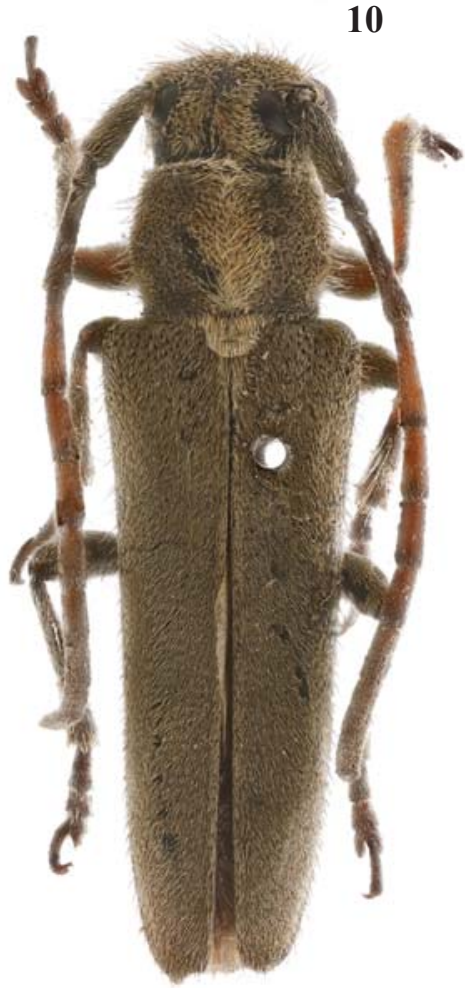

12

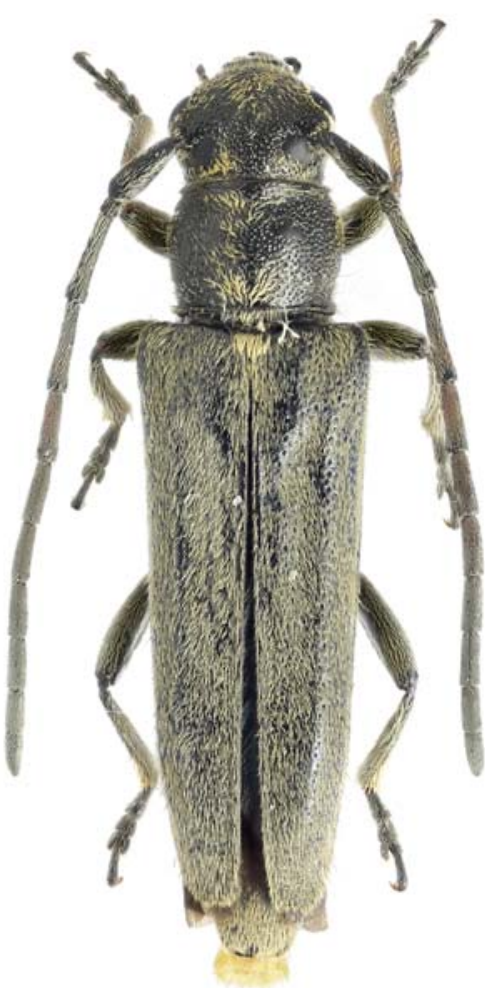

13

Figs 9-14. Habitus and genitalia some species of Phytoecia Dejean, 1835: $9-$ Ph. (Pilemia) halperini Holzschuh, 1999; $10-P h$. (Paracoptosia) brunnerae Sama, 2000; 11-13 - Ph. (Neomusaria) bodemeyeri Reitter 1913 (11 — Iran, Hamadan; 12 - lectotypus, Lorestan; 13 - Iran, Lorestan); 14 - Ph. (Opsilia) prasina Reitter, 1911 (Azerbaijan, Talysh).

Рис. 9-14. Внешний вид и гениталии некоторых видов Phytoecia Dejean, 1835: 9 - Ph. (Pilemia) halperini Holzschuh, 1999; $10-$ Ph. (Paracoptosia) brunnerae Sama, 2000; 11-13 - Ph. (Neomusaria) bodemeyeri Reitter 1913 (11 — Иран, Хамадан; 12 - лектотип, Лорестан; 13 - Иран, Лорестан); 14 - Ph. (Opsilia) prasina Reitter, 1911 (Азербайджан, Талыш). 
NOTES. The new synonymy is based on the original description [Ali, 1987] and examined materials from different parts of the range of this species. This very variable species is characterized by wide diapason of the body size and proportions, and also by colouration of elytra and the pronotum

\section{Dorcadion (Cribridorcadion)}

semibrunneum vlasenkoi Kasatkin, 2020.

MATERIAL: $20^{7}$, Turkey, $\mathrm{Ni}$ de prov., $6 \mathrm{~km} \mathrm{E} \mathrm{Ni} \mathrm{de} \mathrm{city,}$

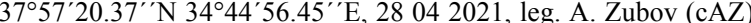

NOTES. This subspecies was described by 13 specimens from Isparta and Antalya provinces. A. Zubov collected two additional males in $\mathrm{Ni}$ de province.

Dorcadion (Cribridorcadion) mniszechi Kraatz, 1873

MATERIAL: $20^{7}, 19$, Turkey, Ankara prov., near Seref-

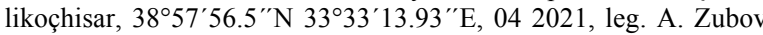
(cAZ).

NOTES. This species known only from some region of Turkey (Sivas, A r , Kars, I dir). The new point is the most western find of D. mniszechi now.
Phytoecia (Pilemia) halperini Holzschuh, 1999 Fig. 9.

MATERIAL: $10^{7}$, Jordan, Irbid reg., Sahm vil., $400 \mathrm{~m}$, 3.05.2003. I.Pijushtch (MNHD).

NOTES. This species is previously known only from Israel [Holzschuh 1999]. The new record for Jordan. This species was described by one female. Sama et al. [2010b] additionally listed two specimens without their sex indication. Here we present brief characteristics of a male: body length is $10 \mathrm{~mm}$, pygidium moderately emarginated, last visible sternite truncate, first sternite with short but well developed denticle on apical margin; aedeagus as on picture (Fig. 9).

Phytoecia (Pilemia) annulata Hampe, 1852

MATERIAL: $10^{7}, 19$, Iran, East Azerbaijan province, near Kandovan vill., 37 $45^{\prime} 44.91^{\prime \prime} \mathrm{N} 46^{\circ} 17^{\prime} 36.65^{\prime \prime} \mathrm{E}, 2005$ 2017, leg. A. Zubov (cAZ)

NOTES. Nonea sp. and N. stenosolen Boissier et Balansa were indicated as host plants of this species [Rejzek et al., 2001]. It was collected on N. anchusoides Boiss. et Buhse in Northern Iran (Âzarbâijân-e Sharqi Province).

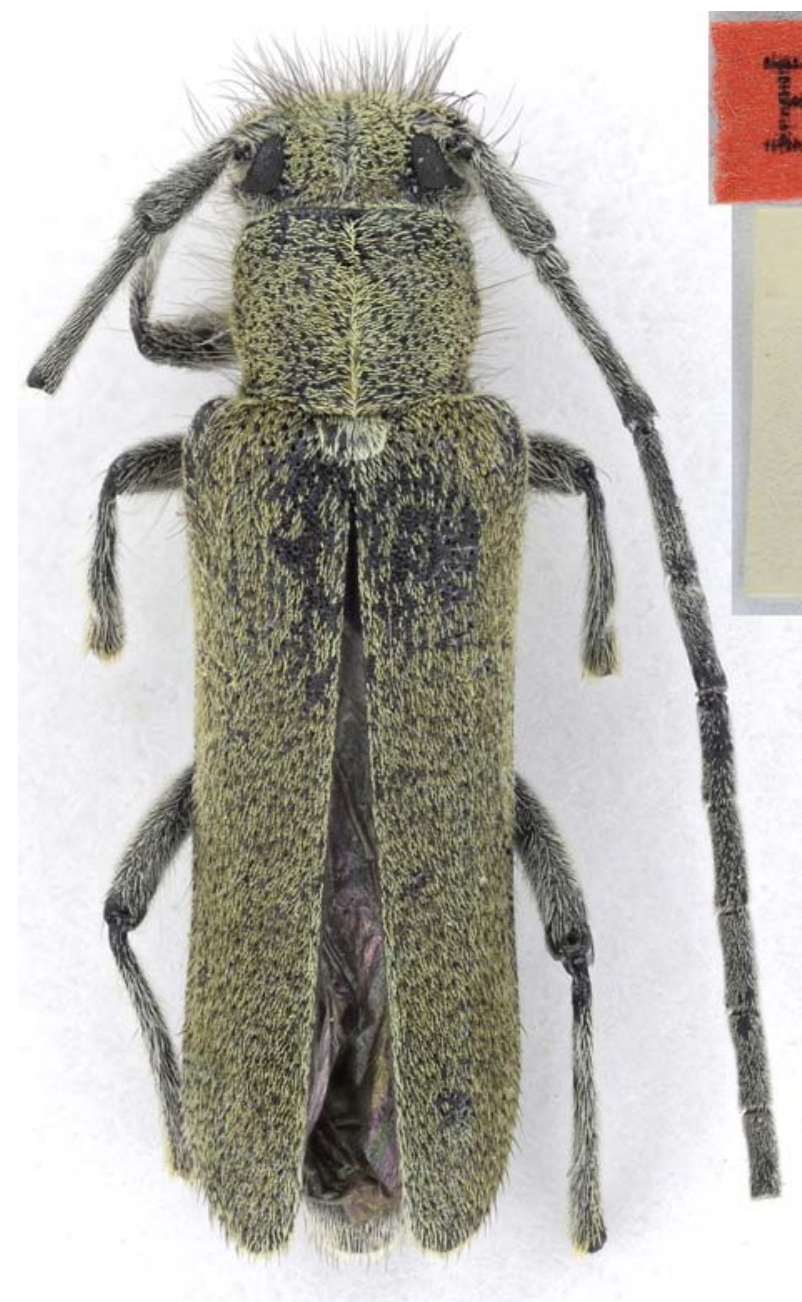

15

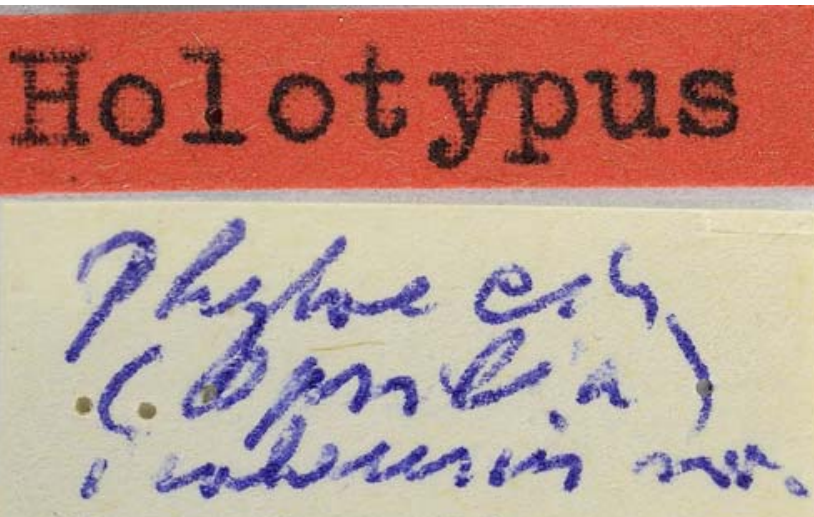

Breuning dét.

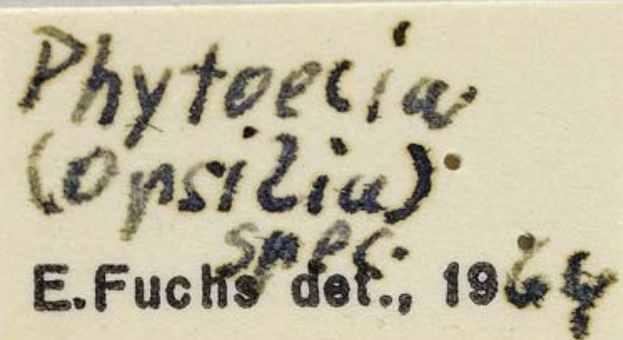

16

Figs 15-16. Holotypus of Phytoecia irakensis Breuning, 1967: 15 — habitus; 16 - labels [Photos by H. Schillhammer].

Рис. 15-16. Голотип Phytoecia irakensis Breuning, 1967: 15 - внешний вид; 16 - этикетки [фото Х. Шилльхаммера]. 


\section{Phytoecia (Musaria)} puncticollis krupitskyi Danilevsky, 2014

MATERIAL: $10^{7}, 1$ 엉, Jordan, Amman reg., $15 \mathrm{~km}$ N Madaba, Hisban vill. Circ., 600 m, 2204 2003, I.Pljusctch leg. (MNHD).

This species was known only from Eastern Turkey [Danilevsky, 2020b]. We found two specimens from Jordan (new record for the country) in the collection of NMHD.

\section{Phytoecia (Paracoptosia) brunnerae Sama, 2000} Fig. 10.

MATERIAL: 19 , Lebanon, Bekaa, $2 \mathrm{~km}$ NW Ainata, 34 ${ }^{\circ} 11^{\prime} 47.51^{\prime \prime N} 36^{\circ} 3^{\prime} 49.33^{\prime \prime E}, 2705$ 2018, leg. Kasatkin D. (cDK).

NOTES. This species was known only from Syria [Sama, 2000; Ali, Rapuzzi, 2016] and Jordan [https://www.biolib.cz/ en/taxonimage/id186210/?taxonid=1240767]. We collected one specimen of this species in Lebanon (new record for the country).

\section{Phytoecia (Paracoptosia) bithynensis (Ganglbauer, 1884)}

MATERIAL: $10^{7}$, Iran, Azerbaijan-e-Qarbi prov., near Piranshahr vill., 16-18 05 2015, Kasatkin D., leg.; 107, 1ㅇ, Iran, Lorestan prov., near Dorud, $5 \mathrm{~km} \mathrm{SW}$ Choghab Dar vill., $33.501061^{\circ} \mathrm{N}$ 49.003441 ${ }^{\circ} \mathrm{E}, 14-15052017$, leg. Kasatkin D. (cDK).
NOTES. This species early was recorded for Turkey [Löbl, Smetana, 2010], Lebanon and Iran [Sama et al, 2010a], but without any localities for the latter country. Iran was excluded from distribution in the last edition of the Palaearctic Catalogue [Danilevsky, 2020b]. We collected some specimens of $P h .(P$. $)$ bithynensis in different provinces of Iran on leaf rosette of Cynoglossum sp. plants together with $P h .(P$.) compacta (Ménétries, 1832).

\section{Eurycoptosia bodoani (Pic, 1912)}

MATERIAL: $10^{7}, 1$ 을 Iran, Zanjan prov., $40 \mathrm{~km}$ NW Bonab, $36.799154^{\circ} \mathrm{N} 48.873157^{\circ} \mathrm{E}, 09-1005$ 2017, leg. Kasatkin D.; 2 , Iran, Elbourz prov., near Gachsar vill., on Anchusa sp., 0106 2014, leg. Kasatkin D.; 1+, Iran, Elbourz prov., near Gachsar vill., on Onosma microcarpum, 2805 2015, leg. Kasatkin D.; 1207, 15ㅇ, Iran, Azerbaijan-e-Qarbi prov., near Rajan, 2505 2014, leg. Kasatkin D., Shokhin I.; 60 7 , 7으, Iran, Azerbaijan-e-Qarbi prov., near Piranshahr vill., 16-18 05 2015, leg. Kasatkin D.; 1 , $10^{7}$ (dead specimens), Iran, Kermanshakh prov., near Shamshir vill., 20-22 05 2015, leg. Kasatkin D. (all in cDK).

NOTES. The species is widespread in Iran from region near Urmia Lake to Zanjan and Lorestan. All specimens were collected in mid-mountains level (1700-2400 m), on gravely open landscapes. Beetles are hiding in leaf rosette of Onosma microcarpum Stev. ex DC (preferred host plant) and Anchusa spp.

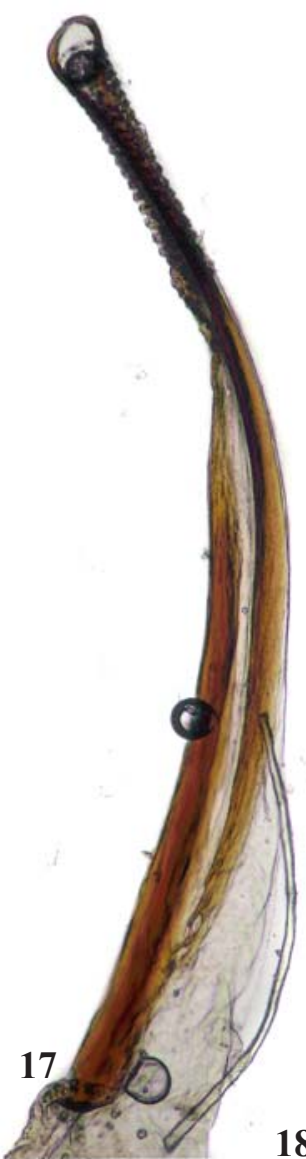

18

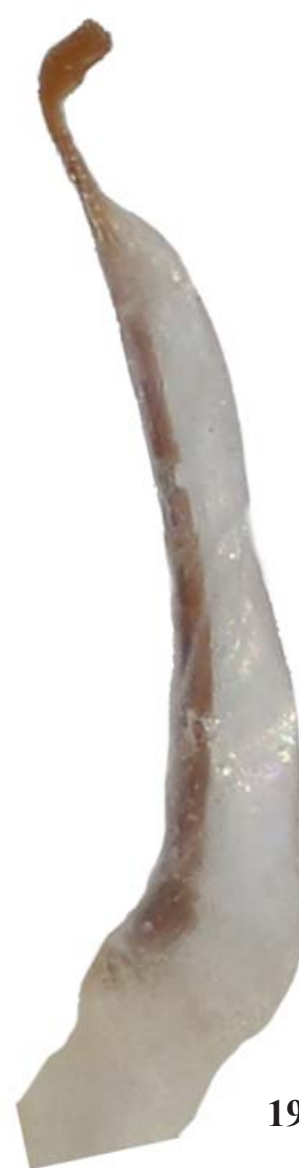

19

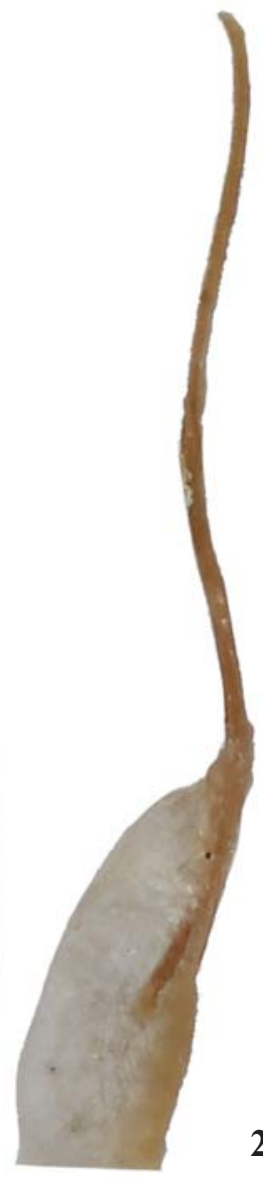

20
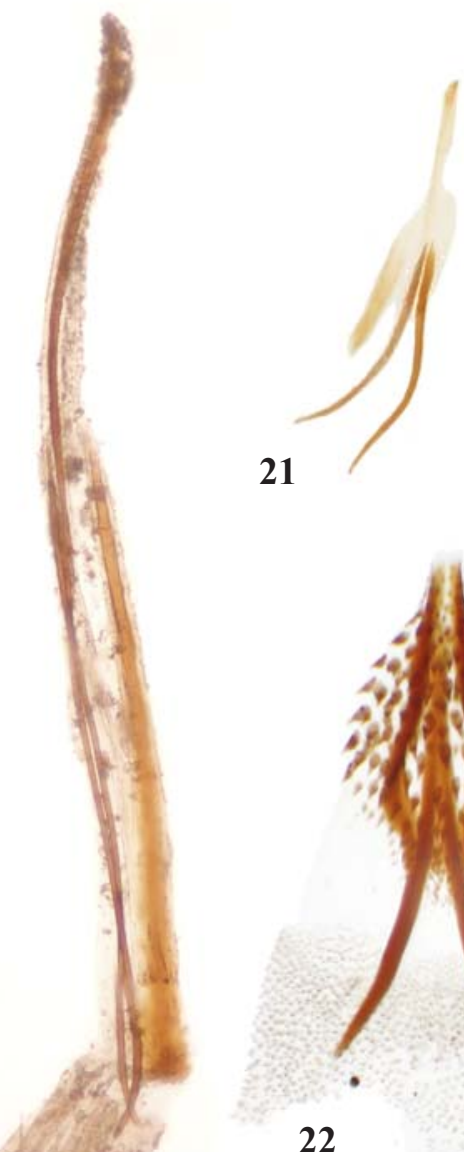

Figs 17-22. Apical part of endophallus some Phytoecia (s.str.) species: 17 - Ph. (s.str.) virgula (Charpentier, 1825); 18 - Ph. (s.str.) nigricornis (Fabricius, 1781); 19 - Ph. (s.str.) icterica (Schaller, 1783); $20-P h$. (s.str.) shokhini Kasatkin, 2010; 21 - Ph. (s.str.) pustulata (Schrank, 1776); 22 - Ph. (s.str.) cylindrica (L., 1758).

Рис. 17-22. Апикальная часть эндофаллуса некоторых видов Phytoecia (s.str.): 17 - Ph. (s.str.) virgula (Charpentier, 1825); 18 Ph. (s.str.) nigricornis (Fabricius, 1781); $19-$ Ph. (s.str.) icterica (Schaller, 1783); $20-P h$. (s.str.) shokhini Kasatkin, 2010; $21-P h$. (s.str.) pustulata (Schrank, 1776); $22-$ Ph. (s.str.) cylindrica (L., 1758). 
Phytoecia (Opsilia) prasina Reitter, 1911

Figs 14-16.

TYPE MATERIAL: Holotype of Ph. Irakensis 10', Irak, Sultan-Bulagh, 25.5.1964, Vartian und Dr. Kasy leg., Holotypus, "Phytoecia irakensis Breuning det." (NMW).

MATERIAL: $20^{7} 1$ 1 , Iran, Azerbaijan-e-Qarbi prov., near Rajan, 2505 2014, leg. Kasatkin D. (cDK); 30 , 1요, Iran, Azerbaijane-Qarbi prov., near Rajan, 24052017 leg. Kasatkin D. (cDK); $10^{7}$, 1 으, Iran, Khamadan prov., $1 \mathrm{~km}$ E Ylfan vill., $34.740476^{\circ} \mathrm{N}$ $48.621117^{\circ}$ E, 10-11 052017 , leg. Kasatkin D. (cDK)

NOTES. This rare species was known only from some localities: Iran, Lorestan (the type locality) and Azerbaijan, Talysh [Miroshnikov, 2009], a host plant was unknown previously. We collected some specimens of $P h$. prasina in Hamedan and Azerbaijan-e-Qarbi Provinces of Iran. All our beetles were collect on Nonea anchusoides Boiss. et Buhse.

Ph. irakensis Breuning, 1967 was described by a single specimen from ' Irak, Sultan-Balagh, 25.5.1963" [Breuning, 1967]. Label data of the holotype is "Irak, Sultan-Bulagh, 25.5.1964" (Fig. 16). Actually, the type locality of Ph.irakensis is located in Iran (Hamadan province, $52 \mathrm{~km}$ NW Hamadan city, Sol ân Bolâghî,) and well known from materials of the Austrian expedition in Afghanistan and Persia [Kaszab, 1965]. Thus, the type locality is located in Iran.

Breuning incorrectly compared $P h$. irakensis with $P h$. coerulescens (Scopoli, 1793). Examination of the holotype (Fig. 15) shown that Ph. irakensis is the male of Ph. prasina prasina. Thus, the following new synonymy is proposed: $P h$. prasina Reitter, $1911=$ Ph. irakensis Breuning, 1967, syn.n.

\section{Phytoecia (Neomusaria) bodemeyeri Reitter 1913} Figs 11-13, 23, 35.

TYPE MATERIAL: "v.Bodemeyer, Persien, Luristan"; "bodemeyeri m. 1911" "coll. Reitter", "Holotypus, $\sigma^{7}$, Phytoecia bodemeyeri Reitter, 1913", "Lectotypus, Phytoecia bodemeyeri Reitter, 1913, G. Sama des. 2002" (HNHM).

MATERIAL: $30^{7}, 2+$, Iran, Khamadan prov., $1 \mathrm{~km}$ E Ylfan vill., 34.740476N 48.621117 E, 10-11 05 2017, leg. Kasatkin D. (cDK); $40^{7}, 3$, Iran, West Azerbaijan, near Garavolkhane vill., Takht-eSoleyman distr. S slope Kuh-e-Belqeys, $36.610612^{\circ} \mathrm{N} 47.307911^{\circ} \mathrm{E}$, 2405 2017, leg. Kasatkin D. (cDK); 19, Iran, Lorestan prov., 24 km S Azna city, $33.279639^{\circ} \mathrm{N} 49.499288^{\circ} \mathrm{E}, 16-17052017$, leg. Zubov A. (cAZ).

NOTES. This unusual species is traditionally placed in the Phytoecia s.str. However, numerous material, collected by author in Iran, old specimens from the type locality and examined type specimens allows us to include $P h$. bodemeyeri to the subgenus Neomusaria Plavilstshikov, 1928 on base of the endophallic structure, the shape of lateral lobes and claws (Figs 17-39). The species has the wide range and demonstrates some variability in colouration of legs, antennae and ventral side of the body.

BIONOMICS. All specimens were collected on Salvia spp., the common host plant for Neomusaria species.
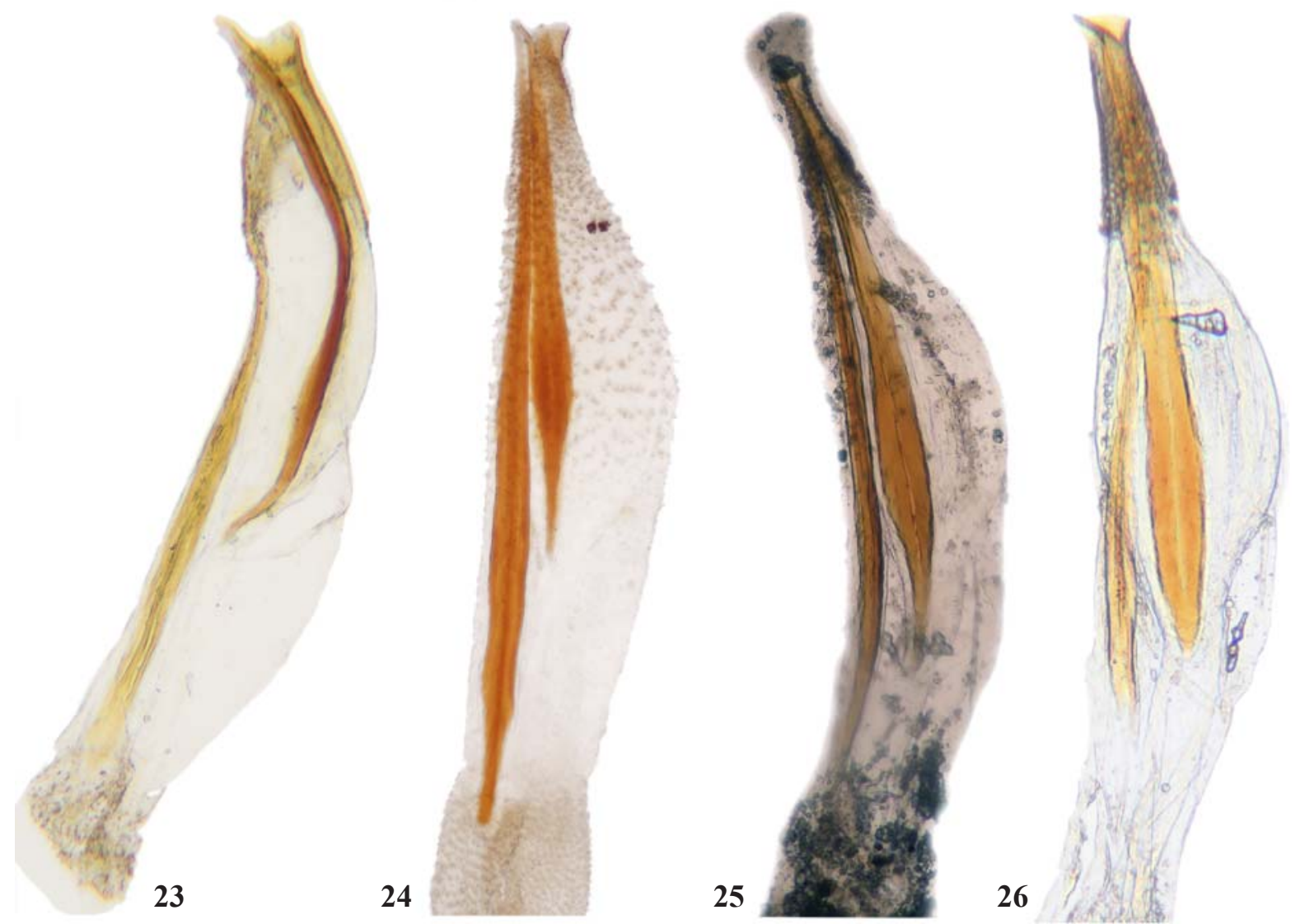

Figs 23-26. Apical part of endophallus some Phytoecia (Neomusaria) species: 23 - Ph. (Neomusaria) bodemeyeri Reitter 1913; 24 Ph. (N.) merkli Ganglbauer, 1884; 25 - Ph. (N.) waltli Sama, 1991; 26 - Ph. (N.) longicornis Pesarini et Sabbadini, 2009.

Рис. 23-26. Апикальная часть эндофаллуса некоторых видов Phytoecia (Neomusaria): 23 - Ph. (Neomusaria) bodemeyeri Reitter 1913; $24-P h$. (N.) merkli Ganglbauer, 1884; $25-P h$. (N.) waltli Sama, 1991; $26-$ Ph. (N.) longicornis Pesarini et Sabbadini, 2009. 
Phytoecia (s.str.) shokhini Kasatkin, 2010

Figs 20, 30, 38.

A position of this species in the system of genus Phytoecia Dejean, 1835 is repeatedly discussed. It was described in Phytoecia s.str. [Kasatkin, 2010], on base of the structure of the apical phallomere (Fig. 20). Danilevsky [2019; 2020a] transferred Ph. shokhini to the subgenus Neomusaria Plavilstshikov, 1928 without any serious reasons. In the same time, he included the very similar (according the original description) Ph. napolovi Danilevsky, 2011 in the nominatypical subgenus. The taxonomic structure of the nominatypical subgenus is also not clear (as seen on Figs 17-22) and needs revision. It is the subject of our following work. The endo-
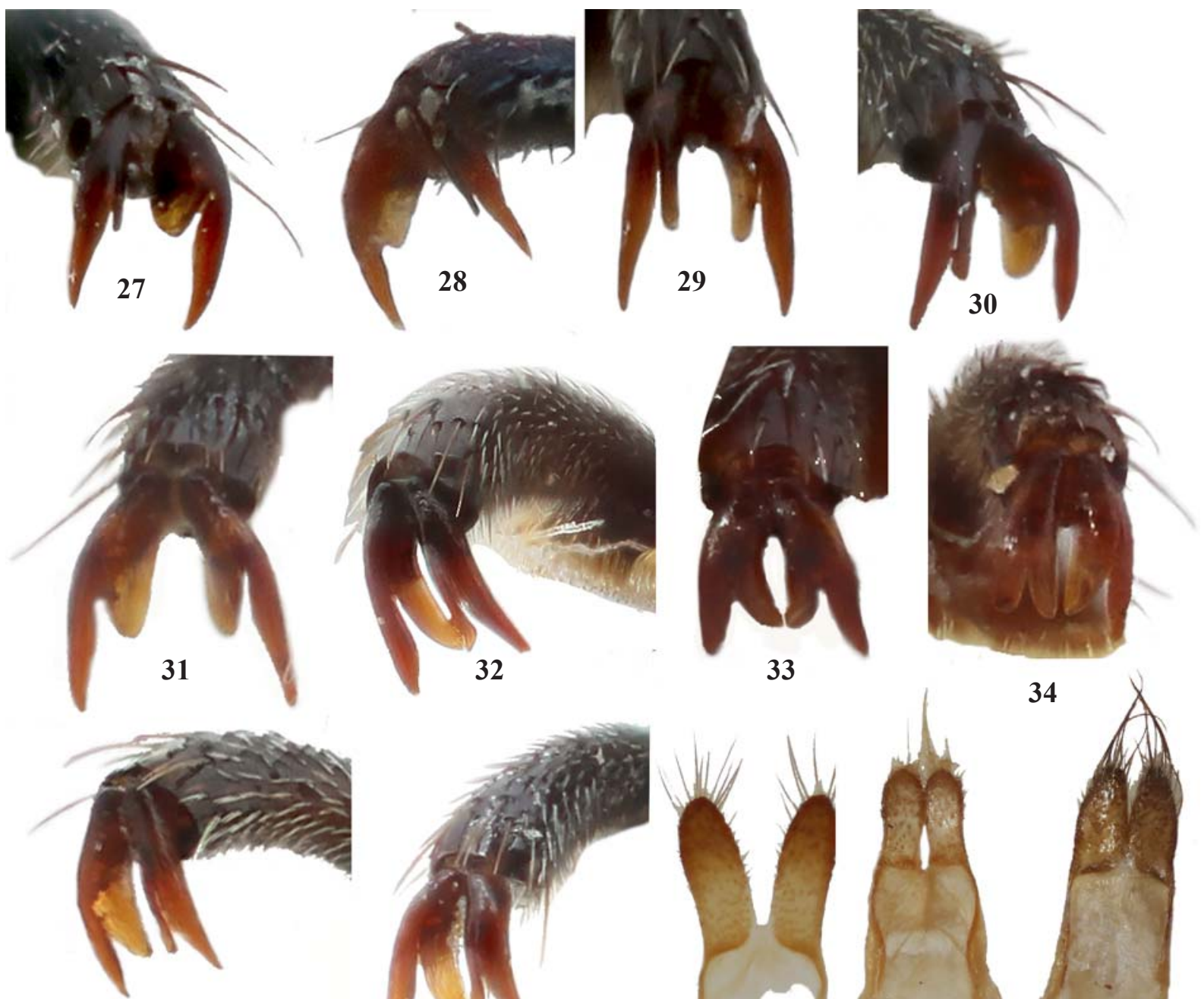

35
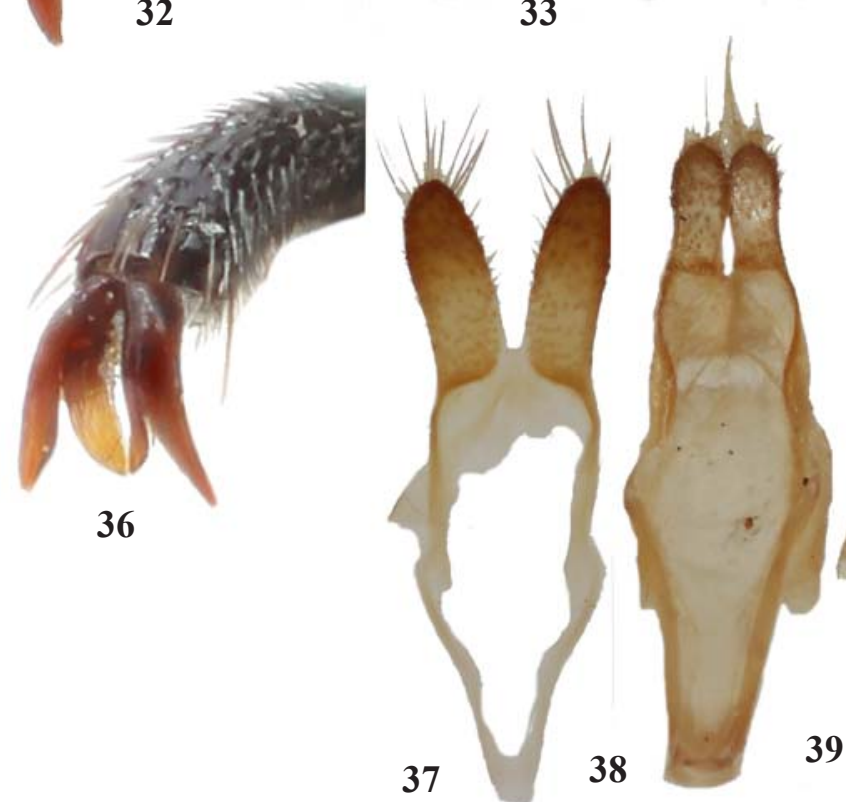

34

36

37

Figs 27-39. Detail of morphology some Phytoecia Dejean, 1835: 27 - Ph. (s.str.) cylindrica (L., 1758); 28 - Ph. (s.str.) caerulea (Scopoli, 1772); 29, 37 - Ph. (s.str.) pustulata (Schrank, 1776); 30, 38 - Ph. (s.str.) shokhini Kasatkin, 2010; 31 - Ph. (s.str.) virgula centaureae Sama, Rapuzzi et Rejzek, 2007; 32- Ph. (Neomusaria) merkli Ganglbauer, 1884; 33 - Ph. (N.) suvorowi Pic, 1905; 37, 34 Ph. (N.) longicornis Pesarini et Sabbadini, 2009; 35 - Ph. (N.) bodemeyeri Reitter 1913; 336- Ph. (N.) waltli Sama, 1991; 27-36 — claws; 37-39 - tegmen.

Рис. 27-39. Детали морфологии некоторых Phytoecia Dejean, 1835: 27 - Ph. (s.str.) cylindrica (L., 1758); 28 — Ph. (s.str.) caerulea (Scopoli, 1772); 29, 37 - Ph. (s.str.) pustulata (Schrank, 1776); 30, 38 - Ph. (s.str.) shokhini Kasatkin, 2010; 31 - Ph. (s.str.) virgula centaureae Sama, Rapuzzi et Rejzek, 2007; 32- Ph. (Neomusaria) merkli Ganglbauer, 1884; 33 — Ph. (N.) suvorowi Pic, 1905; 37, 34 Ph. (N.) longicornis Pesarini et Sabbadini, 2009; 35 - Ph. (N.) bodemeveri Reitter 1913; 336- Ph. (N.) waltli Sama, 1991; 27-36 коготки; 37-39- тегмен. 
phallic structure has already established itself as a reliable character for the separation of subgenera Phytoecia [Kasatkin, 2015, 2018]. The characters of this structure, which were examined by us in 5 species of Neomusaria (Figs 23-26), the shape of tegmen and lateral lobes (Figs 37-39) and the shape of claws (Figs 32-36) clearly indicates that Ph. shokhini belongs to Phytoecia s.str. Also, it is known that all $\mathrm{Ne}$ omusaria species associated with Lamiaceae plants (Salvia), while Ph. shokhini feeding on Apiaceae.

Acknowledgments. The author is grateful to $\dagger$ Dr $\mathrm{O}$. Merkl (HNHM, Budapest, Hungary), Dr A. Solodovnikov (MNHD, Copenhagen, Denmark) and Dr H. Schilhammer (NMW, Wien, Austria), Mr A. Zubov (Moscow, Russia) for the provided material, Dr M. Ranjbar (College of Science BuAli Sina University, Hamadân, Iran) for identification of host plants, Dr H. Schillhammer (NMW, Wien, Austria) for prepared photos of holotype. Dr D. Azar (Lebanese University, Beirut, Lebanon) is acknowledged for his help in the organizing of expedition in Lebanon and translation of Arabic text.

\section{References}

Ali H.A. 1987. A n.sp. of Purpuricenus from Iraq // Iraqi Journal of Science. Vol.28. Nos3-4. P.536-543.

Ali Kh., Rapuzzi P. 2016. Second contribution to the knowledge of Longhorn Beetles of the Syrian Coastal Region (Coleoptera Cerambycidae) // Biodiversity Journal, Vol.7. No.2. P.261-272.

Breuning S. 1967. Österreichische entomologische Expeditionen nach Persien und Afganistan. Beiträge zur Coleopterologie. Teil IV: Cerambycidae: Lamiinae. Beschreibung einer neuen Phytoecia (Opsilia)-Form aus dem Irak // Annalen des Naturhistorischen Museums in Wien. Bd.70 [1966]. 435 p.

Danilevsky M. 2019.http://www.cerambycidae.net/catalog_remarks. pdf (last updated 09.04.2019)

Danilevsky M. 2020a. A new species of Phytoecia (Neomusaria) Plavilstshikov, 1928 from Armenia and a new species of Phytoecia (Parobereina) Danilevsky, 2018 from Iran (Coleoptera, Cerambycidae) // Zootaxa. Vol.4747. No.1. P.196-200.

Danilevsky M. 2020b. Catalogue of Palaearctic Coleoptera, Vol. 6 (1), Chrysomeloidea I (Vesperidae, Disteniidae, Cerambycidae). Revised and updated edition. Leiden / Boston: Brill. xxii, 712 pp.
Holzschuh C. 1999. Beschreibung von 71 neuen Bockkäfern aus Asien, vorwiegend aus China, Laos, Thailand und India (Col., Cerambycidae) // FBVA Berichte-Schriftenreihe der Forstlichen Bundesversuchsanstalt in Wien. Bd.110. S.3-64.

Kasatkin D.G. 2010. A new species of the genus Phytoecia Dejean 1835 (Coleoptera: Cerambycidae) from Eastern Turkey // Caucasian Entomological Bulletin. Vol.6. No.1. P.61-62. Plates 6.

Kasatkin D.G. 2015. A new subgenus of the genus Phytoecia Dejean, 1835 (Coleoptera: Cerambycidae: Lamiinae) // Russian Entomological Journal. Vol.24. No.2. P.127-131.

Kasatkin D.G. 2018. Pseudopilemia - a new subgenus of the genus Phytoecia Dejean, 1835 (Coleoptera: Cerambycidae) // Russian Entomological Journal. Vol.27. No.2. P.157-160.

Kaszab Z. 1965. Osterreichische entomologische Expedition nach Persien und Afghanistan // Annalen des Naturhistorischen Museums in Wien. Bd.68. S.667-670.

Löbl I., Smetana A. 2010. Catalogue of Palaearctic Coleoptera. Chrysomeloidea // I. Löbl, A. Smetana (eds.). Stenstrup: Apollo books. Vol.6. P.1-924.

Miroshnikov A.I. 2009. [Contribution to the knowledge of the littleknown longicorn beetles species - Phytoecia (Opsilia) prasina Reitter, 1911 (Coleoptera: Cerambycidae)] // Caucasian Entomological Bulletin. Vol.5. No.2. P.243-244 [in Russian].

Miroshnikov A.I. 2011. [Contribution to the knowledge of the longicorn beetles (Coleoptera, Cerambycidae) of the Caucasus. 7. Notes on the distribution of some species] // Entomologitcheskoe Obozrenie. Vol.90. No.3. P.553-569 + Figs 1-15 [in Russian].

Rejzek M., Sama G., Alziar G., 2001. Host plants of several herbfeeding Cerambycidae mainly from east Mediterranean region (Coleoptera: Cerambycidae) // Biocosme Mésogéen. Vol.17. No.4. P.263-294.

Sama G. 2000. Su alcuni nuovi o interessanti Cerambicidi del medio Oriente (Insecta Coleoptera Cerambycidae) // Quaderni di Studi e Notizie di Storia Naturale della Romagna. Vol.13 (supplemento). P.91-105, 12 Figs.

Sama G., Rapuzzi P., Kairouz A. 2010a. Catalogue commenté des Cerambycidae du Liban // Quaderno Studi e Notizie di Storia Naturale della Romagna. Vol.30. P.131-201.

Sama G., Buse J., Orbach E., Friedman A. L. L., Rittner O., Chikatunov V. 2010b. A new catalogue of the Cerambycidae (Coleoptera) of Israel with notes on their distribution and host plants // Munis Entomology \& Zoology. Vol.5. No.1. P.1-51.

Villiers A. 1967: Contribution à la faune de 1'Iran. I: Coléoptéres Cerambycidae// Annales de la Société Entomologique de France. N.s. Vol.3. P.327-379. 